\title{
MEKANISASI TEKNOLOGI PENGOLAHAN PANGAN PADA USAHA OLAHAN TEPUNG BERAS DAN KASAVA DI KABUPATEN BLITAR
}

\author{
Mechanization of Food Processing Technology at Rice Flour and Cassava Processing \\ Industries at Blitar Regency \\ Jaya Mahar Maligan'), M. Bagus Hermanto ${ }^{2)}$ \\ ${ }^{1)}$ Jurusan Teknologi Hasil Pertanian, FTP Universitas Brawijaya, Jl. Veteran, Malang 65145 \\ 2) Jurusan Keteknikan Pertanian, Universitas Brawijaya, Jl. Veteran, Malang 65145 \\ email: maharajay@gmail.com
}

\begin{abstract}
In this community service, mechanical technology that has been applied is the process of packaging using vertical packaging machine in small medium entreprise (SME) Mony, grating process, additional stove and steamer in SME Agro Sukses Mulia. Other applied transfer of technology is oil spinning at SME Mony and mechanical grater in SME Rizky Abadi. Socialization of Good Manufacturing Practices (GMP) and sanitary standards have also been conducted at all SMEs in Papungan Village, District of Kanigoro, Blitar Regency. After implementation of this program, all SMEs have been able to increase its production capacity and efficiency. SME Mony is able to increase the capacity of opak gambir packaging and kembang goyang into 80-100 packs per hour and matari product drier with the oil draining technology. Successful SME Agro Majesty able to increase the capacity of steaming rengginang cassava into $2 X$ is 160 prints all process and increase the capacity of pemarutan cassava into 1 1.5 hours to 30-40 kg of cassava. Rizky Abadi SMEs can also improve the efficiency pemarutan 30 coconuts within 1 hour in the manufacturing process opaque Gambir.
\end{abstract}

Keywords: improvement, production capacity, production efficiency, GMP

\begin{abstract}
ABSTRAK
Pada pengabdian masyarakat ini, alih teknologi mekanis yang telah diaplikasikan adalah proses pengemasan menggunakan mesin pengemas vertikal di UKM Mony, proses pemarutan mekanis serta penambahan kompor dan panci pengukus di UKM Agro Sukses Mulia. Alih teknologi lain adalah proses pengatusan minyak di UKM Mony dan pemarut mekanis di UKM Rizky Abadi. Sosialisasi GMP dan standar sanitasi juga telah dilaksanakan pada ketiga UKM di Desa Papungan Kecamatan Kanigoro Kabupaten Blitar ini. Setelah dilaksanakannya kegiatan IbM, ketiga UKM telah mampu meningkatkan kapasitas dan efisiensi produksinya. UKM Mony mampu meningkatkan kapasitas pengemasan opak gambir dan kembang goyang menjadi 80-100 kemasan per jam dan produk matarinya lebih kering dengan teknologi penirisan minyak. UKM Agro Sukses Mulia mampu meningkatkan kapasitas pengukusan rengginang kasava menjadi $2 x$ lipat yaitu 160 cetakan sekali proses dan meningkatkan kapasitas pemarutan singkong menjadi 1-1.5 jam untuk 30-40 kg singkong. UKM Rizky Abadi juga dapat meningkatkan efisiensi pemarutan 30 butir kelapa dalam waktu 1 jam dalam proses pembuatan opak gambir.
\end{abstract}

Kata kunci: peningkatan, kapasitas produksi, efisiensi produksi, GMP

\section{PENDAHULUAN}

Kabupaten Blitar merupakan salah satu dari 22 kota/kabupaten di Jawa Timur yang merupakan kawasan agropolitan.
Pengembangan Kawasan Agropolitan merupakan salah satu pendekatan pembangunan pedesaan berbasis pertanian dalam artian luas), dengan menempatkan 'kota-tani' sebagai pusat kawasan dan ketersediaan sumberdaya, modal tumbuh 
dan berkembang, dan mendorong usaha agrobisnis antar desa-desa kawasan (hinterland) dan desa-desa sekitarnya (Bappeda Jatim, 2011).

Di Jawa Timur saat ini telah terbentuk kawasan agropolitan mandiri yaitu Kota Batu, Kabupaten Mojokerto, Ngawi dan Banyuwangi. Selanjutnya, dalam pengembangannya sampai dengan tahun 2011 telah bertambah sebanyak 18 kawasan pengembangan baru, yang meliputi: Kabupaten Lumajang, Bangkalan, Tulungagung, Trenggalek, Pamekasan, Pasuruan, Madiun, Blitar, Ponorogo dan Pacitan, Nganjuk, Probolinggo, Malang, Lamongan, Tuban, Bondowoso, Bojonegoro, dan Jombang sebagai kawasan agropolitan mandiri, sehingga jumlah kawasan agropolitan di Jawa Timur menjadi 22 lokasi (Pedum Agropolitan Jatim, 2011).

Kabupaten Blitar mempunyai kawasan agropolitan dengan pusatnya adalah Kecamatan Kanigoro. Masingmasing desa di Kecamatan Kanigoro mempunyai basis olahan hasil pertanian yang berbeda. Desa Papungan merupakan desa di Kecamatan Kanigoro yang merupakan sentra produk olahan berupa opak gambir berbahan tepung beras, kembang goyang atau matari dari ubi ungu, dan olahan kasava berupa rengginang dan kerupuk kasava. Produk-produk olahan tersebut dapat dilihat pada Gambar 1.
Produk pangan olahan Desa Papungan dipasarkan cukup luas yaitu di Blitar, Malang, dan Tulungagung untuk kerupuk dan rengginang kasava dengan sistem pemasaran sistem putus dan konsinyasi. Opak gambir MONY dipasarkan Malang, Blitar Raya, Madura, Jakarta dan sudah menjajagi pemasaran online. Ibu Nining selain memproduksi opak gambir sendiri, juga menampung opak gambir dari perajin lain di Desa Papungan untuk dikemas dan kemudian dipasarkan. Sebagian besar usaha mikro pangan di Desa Papungan memproduksi opak gambir. Opak gambir produksi Ibu Siti Fatimah dipasarkan di Malang, Tulungagung, Pare/Kediri, sampai Kalimantan. Ibu Siti Fatimah mempunyai tenaga pemasaran yang memasarkan produknya sehingga pasarnya sudah cukup luas.

Proses pengolahan opak gambir merek MONY dan Rizqi Abadi pada prinsipnya sama yaitu kelapa diparut untuk diambil santan kentalnya, kemudian dibuat adonan cair (batter) dengan tepung gula, telur, gula pasir, dan tepung beras, dicetak dan digulung, kemudian ditimbang dan dikemas. Proses pengolahan opak gambir di mitra Ibu Siti Fatimah dapat dilihat pada Gambar 2.
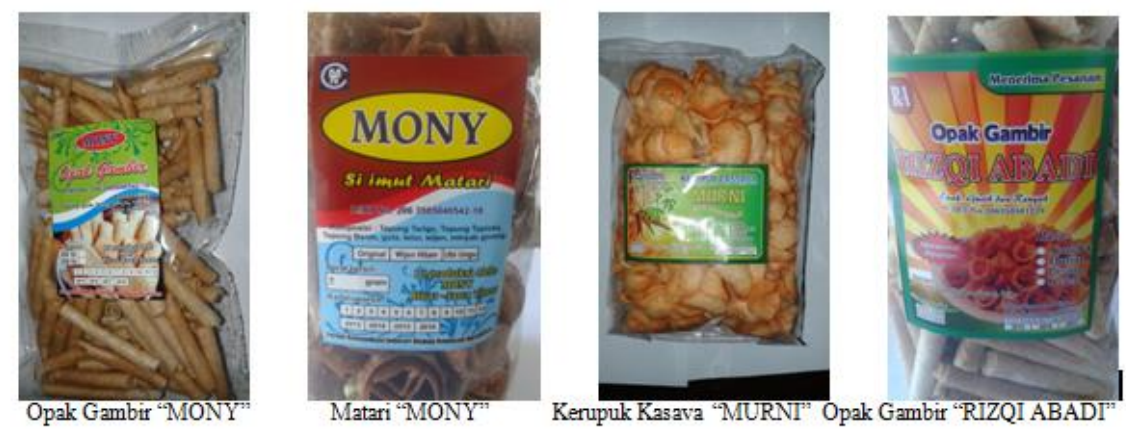

Gambar 1. Produk olahan Desa Papungan, Kecamatan Kanigoro, Kabupaten Blitar 


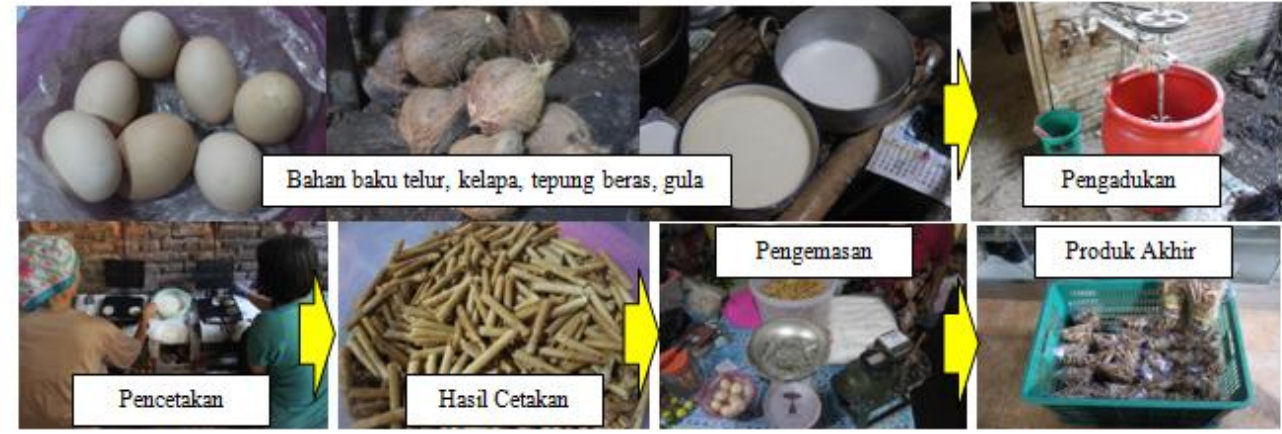

Gambar 2. Proses pengolahan opak gambir

Pembuatan matari atau kembang goyang ubi ungu hampir mirip dengan pembuatan kembang goyang, yaitu kelapa diparut untuk diambil santan kentalnya, kemudian dibuat adonan cair (batter) dengan tepung gula, ubi ungu kukus yang sudah dihaluskan, telur, gula pasir, dan tepung beras, selajutnya cetakan dicelupkan dan adonan sampai menempel di cetakan, cetakan kemudian dicelupkan ke dalam minyak goreng panas, kemudian digoreng sambil digoyang-goyang sampai matang, ditiriskan, ditimbang dan dikemas. Alat pencetak matari dapat dilihat pada Gambar 3.

Alat proses yang digunakan oleh kelompok usaha pangan olahan Desa Papungan dapat dilihat pada Gambar 3 yaitu pemarut singkong ukuran kecil (Gambar 3a) dengan kapasitas $3 \mathrm{~kg} / \mathrm{jam}$, pengaduk atau mixer sederhana (Gambar 3b) untuk opak gambir dan matari, pengukus kapasitas kecil (Gambar 3c) yaitu $5 \mathrm{~kg} /$ batch untuk pengolahan rengginang dan kerupuk kasava, pengepres singkong (Gambar 3d), dan cetakan kembang goyang atau matari (Gambar 3e). Semua alat proses terlihat kumuh/kotor dan sederhana dengan tempat produksi yang juga kurang bersih. Terlihat bahwa mitra belum menerapkan standar sanitasi dan hygiene dalam proses produksinya. Prinsip-prinsip Good Manufacturing Practices (GMP) juga belum diimplementasikan oleh mitra, terlihat dari bahan mentah (telur) yang diletakkan dekat produk jadi (Gambar 2), bahan baku yang diletakkan di lantai (Gambar 2), lantai produksi dari tanah (Gambar 3), pekerja yang tidak menggunakan sarung tangan (Gambar 2), pekerja yang tidak menggunakan tutup kepala (Gambar 2), dan banyak hal lainnya yang belum sesuai GMP.

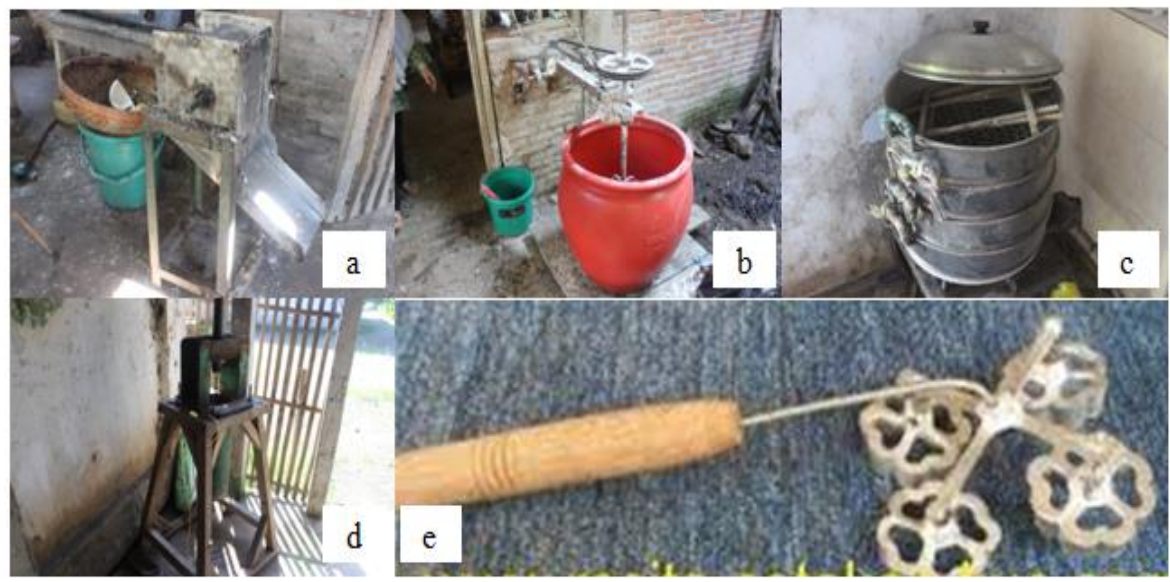

Gambar 3. Alat pengolahan yang dimiliki mitra (a) pemarut singkong, (b) mixer, (c) pengukus, (d) pengepres, dan (e) cetakan matari 
Opak gambir merek Rizqi Abadi berbeda dengan merek MONY karena pada opak gambir Rizqi Abadi diberi aneka rasa buah-buahan seperti nangka, durian, pisang, dan lainnya dengan jumlah buah yang digunakan sebanyak 2 ons untuk $1 \mathrm{~kg}$ tepung. Masalah yang dihadapi mitra Ibu Siti Fatimah dalam memproduksi opak gambir merek Rizqi Abadi adalah pemarutan kelapa dengan kapasitas kecil sedangkan jumlah kelapa yang harus tiap hari dengan total produksi per hari $20 \mathrm{~kg}$ terigu adalah 40-60 butir. Peningkatan kapasita pemarutan menjadi masalah mendesak bagi mitra. Masalah lain adalah proses pengemasan yang masih menggunakan sealer manual padahal dalam 1 hari mitra mengemas sekitar 100 kemasan per hari.

Masalah yang dihadapi oleh Ibu Nining dalam memproduksi opak gambir dan kembang goyang ubi ungu adalah pengemasan yang masih menggunakan sealer manual sehingga proses pengemasan memakan waktu lama. Ibu Nining juga berperan sebagai penampung produk opak gambir dari warga Desa Papungan lainnya. Peningkatan kapasitas diperlukan untuk mengefisienkan proses pengemasan. Masalah lain adalah produk kembang goyang yang berminyak akibat bentuknya mirip bunga dan banyak lekukan. Pengatusan minyak diperlukan untuk mendapatkan produk kembang goyang yang tidak berminyak. Adanya minyak ini menyebabkan produk kembang goyang mudah mengalami ketengikan karena minyak teroksidasi sehingga rentang waktu pemasaran menjadi terbatas. Menurut Choe dan Min (2006), produk oksidasi sekunder berkaitan dengan bau tengik. Radikal bebas hasil oksidasi lipid juga menyebabkan berbagai penyakit (Lee et al., 2004).

Proses pengolahan rengginang kasava dan kerupuk kasava sebagai produk pangan olahan Desa Papungan uang lain adalah sebagai berikut: bahan baku singkong setelah dikupas dan dicuci, diparut dengan pemarut seperti ditunjukkan Gambar 3a. Selanjutnya cairan singkong dikeluarkan dengan cara dipres dengan alat pres sederhana (Gambar 3d). Cairan yang dihasilkan diendapkan semalam untuk diambil patinya. Ampas dari pengepresan (onggok) dimasukkan kulkas semalam, kemudian keesokan harinya dicampur dengan pati dari endapan dan diaduk sampai terbentuk buliran-buliran atau granula. Proses pengadukan ini (granulasi) memakan waktu lama yaitu 4 jam dengan jumlah tenaga kerja 2 orang. Hal ini yang menyebabkan produksi rengginang kasava menjadi terbatas padahal permintaan tinggi karena jumlah pesaing yang hampir tidak ada. Ibu Murnami memproduksi rengginang kasava $50 \mathrm{~kg} /$ per produksi dengan frekuensi produksi seminggu 3 kali. Selanjutnya setelah terbentuk buliran, buliran tersebut dimasukkan ke dalam cetakan dari tatakan (Gambar 4) dan buliran singkong dipipihkan sampai satu sama lain buliran saling berlekatan. Selanjutnya cetakan dikukus dalam dandang seperti ditunjukkan Gambar 3c. Setelah matang, rengginang kasava dkeluarkan dari cetakannya untuk kemudian dijemur sampai kering. Masalah yang dihadapi pada produksi rengginang kasava adalah granulasi yang lama, proses pemarutan dengan kapasitas kecil, dan proses pengukusan yang lama akibat kapasitasnya yang rendah.

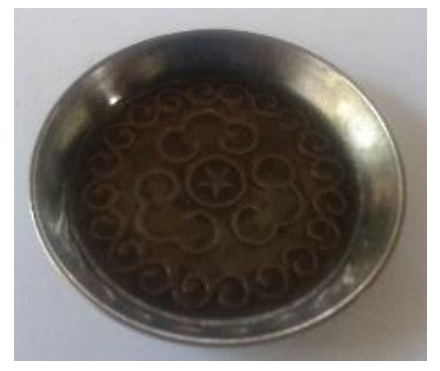

Gambar 4. Cetakan rengginang kasava

Proses pengolahan kerupuk kasava lebih sederhana dibandingkan rengginang kasava akan tetapi alat proses yang digunakan adalah sama. Singkong setelah diparut diperas menggunakan pengepres hidrolik. Cairan pengepresan diendapkan untuk diambil patinya. Ampas singkong kemudian dicampur dengan pati dan 
dimasukkan ke dalam plastik kerupuk untuk dibuat lontongan. Selanjutnya lontongan dikukus sampai matang. Lontongan didinginkan dan setelah padat diiris untuk kemudian dijemur. Irisan kerupuk yang sudah kering digoreng dan diberi bumbu. Permasalahan yang dihadapi mitra untuk proses produksi kerupuk kasava adalah kapasitas pemarutan dan pengukusan yang rendah.

Dari hasil uraian sebelumnya, dapat disimpulkan bahwa masalah yang dihadapi mitra pada proses produksi opak gambir adalah kapasitas pemarutan yang rendah, kapasitas pengemasan yang terbatas. Pada proses produksi kembang goyang permasalahannya adalah produk yang berminyak. Pada proses produksi rengginang dan kerupuk kasava, permasalahan mitra adalah pemarutan dan yang berkapasita rendah. Granulasi manual juga menjadi kendala yang dihadapi mitra pada proses produksi rengginang kasava. Dari hasil diskusi dengan mitra, disepakati program untuk mengatasi permasalahanpermasalahn tersebut adalah peningkatan kapasitas produksi dan pengemasan opak gambir, penuntasan minyak pada produk kembang goyang, peningkatan kapasitas pemarutan dan pengukusan rengginang dan kerupuk kasava, serta peningkatan efisiensi granulasi. Mitra juga perlu diberi wawasan tentang Good Manufacturing Practices dan standar sanitasi industri pangan supaya produk yang dihasilkan bermutu konsisten dan aman.

\section{METODOLOGI}

Tujuan dari kegiatan IbM ini adalah memecahkan permasalahan yang dihadapi mitra pada proses produksi opka gambir, kembang goyang, rengginang kasava, dan kerupuk kasava. Tujuan lainnya adalah pengenalan GMP dan sanitasi industri pangan dengan. Untuk mencapai tujuan tersebut, solusi yang ditawarkan adalah sebagai berikut:

\section{Peningkatan efisiensi dan kapasitas produksi opak gambir}

Hasil diskusi dengan mitra Ibu Nining Siti Muyasaroh dan Ibu Siti Fatimah terungkap bahwa masalah yang dihadapi mitra adalah kapasitas pemarutan kelapa yang terbatas. Ibu Siti Fatimah dengan produksi opak gambir $15-20 \mathrm{~kg} / \mathrm{hari}$ membutuhka kelapa 20-30 butir/hari yang diparut dengan kapasitas pemarut $3 \mathrm{~kg} / \mathrm{jam}$ sehingga membutuhkan waktu pemarutan 34 jam. Peningkatan kapasitas pemaritan dibutuhkan mitra untuk memperpendek waktu pemarutan sehingga mitra dapat meningkatkan kapasitas produksinya. Opak gambir aneka rasa produksi Ibu Siti Fatimah sudah mempunyai pasar yang luas sehingga peningkatan kapasitas produksi masih dapat diserap oleh pasar. Alih teknologi mekanis pemarut mengunakan mesin pemarut. Dengan mesin pemarut ini, proses pemarutan dapat dipersingkat menjadi 1-2 jam.

Permasalahan lain yang dihadapi kedua mitra dalam produksi opak gambir adalah proses pengemasan yang memakan waktu lama. Mitra Ibu Siti Fatimah memproduksi 100 kemasan per hari, sedangkan Ibu Nining Siti Muyasaroh selain memproduksi opak gambir produksi sendiri juga memasarkan opak gambir produksi warga Desa Papungan yang lain. Alih teknologi pengemas kontinyu vertikal diperlukan untuk mempercepat proses pengemasan sehingga mitra dapat mempersingkat proses pengemasan dari 25 kemasan/jam menajdi 100 kemasan/jam.

\section{Peningkatan mutu kembang goyang}

Masalah yang dihadapi kembang goyang MONY produksi Ibu Nining Siti Muyasaroh adalah produk yang berminyak akibat bentuk kembang goyang yang mirip bunga mawar sehingga penuh lekukan. Untuk menghilangkan minyak diperlukan mesin pengatus minyak (spinner) tetapi dengan kecepatan putaran rendah karena produk kembang goyang mudah patah. Spinner yang dirancang untuk mitra harus 
mempunyai rpm yang rendah sehingga harus didesain khusus sesuai dengan karakteristik produk. Spinner.

\section{Peningkatan efisiensi dan kapasitas produksi rengginang dan kerupuk kasava}

Pada proses pembuatan rengginang dan kerupuk kasava, mitra Ibu Murnami mempunyai masalah pemarutan singkong dengan kapasitas kecil, proses granulasi yang memakan waktu lama, dan proses pengukusan berkapaistas kecil. Dari hasil diskusi dengan mitra, mitra menginginkan ada alat yang dapat membantu proses granulasi sehingga dari manual bisa dilakukan secara mekanis. Alih teknologi pengaduk untuk granulasi dapat dilihat pada Gambar 8. Adanya alih teknologi ini dapat meningkatkan efisiensi granulasi dari 4 jam untuk $30 \mathrm{~kg}$ singkong menjadi 15 menit untuk $5 \mathrm{~kg}$.

Masalah lain yang dihadapi mitra adalah kapasitas pengukusan menggunakan dandang skala rumah tangga dengan kapasitas 80 cetakan rengginang. Pengukus juga dibutuhkan pada proses pengolahan kerupuk untuk gelatinisasi pati pada adonan kerupuk. Alat pengukus bertingkat dengan kapasitas sekitar 400 cetakan/proses dapat membantu mitra meningkatkan efisiensi pengukusan. Mesin pengukus berbahan bakar LPG ini dapat dilihat pada Gambar 9. Adanya mesin ini dapat meningkatan kapasitas pengukusan sebanyak 5 kali lipat sehingga mitra berpeluang untuk meningkatkan kapasitas produksi rengginang dan kerupuk kasava.

\section{Peningkatan pemahaman mitra terhadap GMP dan sanitasi industri pangan}

Dari Gambar 2 dan 3 terlihat bahwa mitra belum sepenuhnya menerapkan prinsip-prinsip GMP (Good Maunfacturing Practices) atau cara-cara pengolahan pangan yang baik. Semua mitra tergabung dalam Forum Komunikasi Industri Pangan Olahan Agropolitan Blitar. Forum komunikasi (Forkom) tersebut telah mendapat pembinaan dari pemerintah daerah. Hanya saja sering kali pelatihan yang diadakan instansi pemerintah uuntuk pelaku usaha dihadiri oleh perwakilan Forkom sehingga tidak bisa sepenuhnya hasil pelatihan ditransfer kepada seluruh anggota. Hal ini yang menyebabkan mitra belum memahami dengan baik GMP. Demikian juga, sanitasi dan hygiene merupakab masalah yang belum menjadi perhatian utama mitra. Terlihat dari Gambar 2 dan 3 bahwa prinsipprinsip sanitasi pekerja, peralatan, dan ruang produksi belum diterapkan dengan baik. Oleh karena itu, melalui Program IbM ini akan dilakukan pelatihan GMP dan sanitasi industri pangan. Mitra juga dibantu penerapan untuk pengendalian proses, sanitasi pekerja, dan SOP sanitasi peralatan dan ruang produksi. Untuk sanitasi ruang produksi tampaknya mitra belum bisa segera mengimplementasikan setelah pelatihan karena memerlukan dana yang tidak sedikit untuk menata ruang produksi. Setidaknya melalui Program IbM ini mitra sudah mendapatkan pemahaman tentang sanitasi ruang produksi yang tepat.

\section{HASIL DAN PEMBAHASAN}

\section{Peningkatan efisiensi dan kapasitas produksi opak gambir}

Permasalahan yang dihadapi Ibu Siti Muyasaroh (UKM Mony) dalam produksi opak gambir adalah proses pengemasan yang memakan waktu lama. Alih teknologi pengemas kontinyu vertikal diperlukan untuk mempercepat proses pengemasan sehingga mitra dapat mempersingkat proses pengemasan dari 25 kemasan/jam menjadi $100 \mathrm{kemasan} / \mathrm{jam}$.

Demikian pula pada UKM Rizky Abadi, permasalahan yang dihadapi oleh Ibu Siti Fatimah selaku pemilik UKM adalah peningkatan kapasitas pemarutan kelapa dalam pembuatan opak gambir. Ibu Siti Fatimah membutuhkan 20-30 butir kelapa perhari. Oleh karena itu introduksi teknologi pemarutan kelapa menggunakan mesin pemarut kelapa dirasakan penting bagi UKM tersebut. Gambar mesin pemarut 
kelapa yang diintroduksikan pada UKM

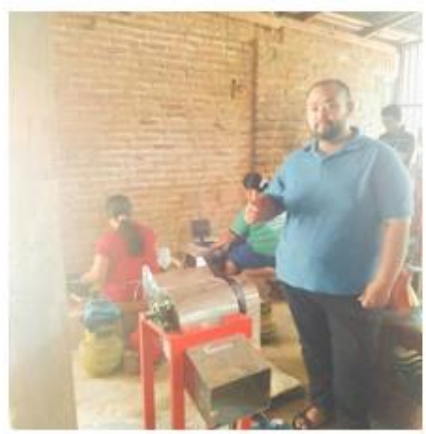

Rizky Abadi dapat dilihat pada Gambar 5.

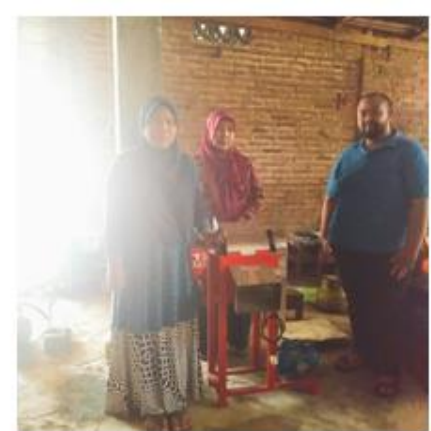

Gambar 5. Introduksi mesin pemarut kelapa di UKM Rizky Abadi

Hasil introduksi teknologi yang telah dilakukan menunjukkan bahwa UKM Rizky Abadi mampu meningkatkan kecepatan pemarutan 30 butir kelapa menjadi 1 jam, dimana sebelum program IbM diperlukan waktu 3-4 jam. Sedangkan di UKM Mony, setelah program IbM, terjadi peningkatan kapasitas pengemasan dari 25 kemasan per jam, menjadi 80-100 kemasan per jam.

\section{Peningkatan efisiensi dan kapasitas produksi rengginang dan kerupuk kasava}

Masalah yang dihadapi mitra Ibu Munarmi (UKM Agro sukses mulia) adalah kapasitas pengukusan dan granulasi. Sebelumnya UKM menggunakan dandang skala rumah tangga dengan kapasitas 80 cetakan rengginang. Pengukus juga dibutuhkan pada proses pengolahan kerupuk untuk gelatinisasi pati pada adonan kerupuk. Alat pengukus bertingkat dengan kapasitas
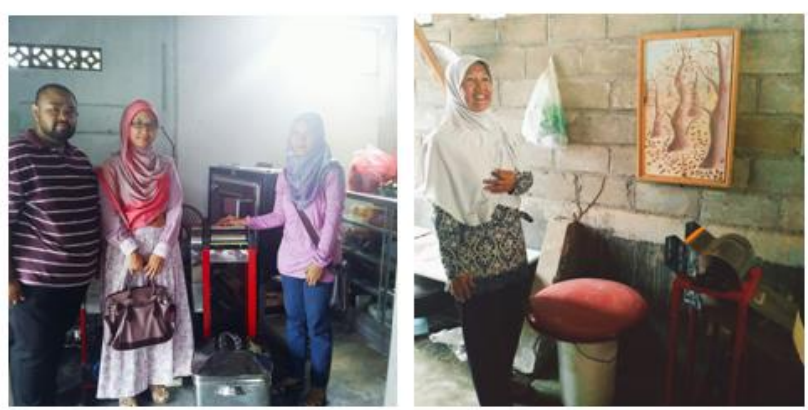

Gambar 6. Introduksi mesin pemarut dan pengukus di UKM Agro Sukses Mulia sekitar 400 cetakan/proses dapat membantu mitra meningkatkan efisiensi pengukusan.

Dalam pelaksanaannya, kami belum dapat membantu pengadaan mesin pengukus vertikal dan granulasi karena keterbatasan biaya sehingga kami alihkan menjadi penambahan dandang pengukus dan kompor. Selain itu introduksi mesin pemarut mekanis juga diaplikasikan bagi UKM tersebut untuk meningkatkan kapasitas produksinya. Introduksi mesin pemarut dan pengukus di UKM Agro Sukses Mulia disajikan pada Gambar 6.

Setelah kegiatan IbM, UKM Agro Sukses mulia dapat meningkatkan kapasiitas pengukusan menjadi $2 x$ lipat yaitu 160 cetakan pengukusan sekali proses. Sedangkan dengan adanya introduksi mesin pemarut, UKM mampu meningkatkan efisiensi pemarutan $30-40 \mathrm{~kg}$ singkong dalam waktu antara 1-1.5 jam, lebih cepat dari sebelum program $\mathrm{IbM}$ yang memakan waktu 2-3 jam. 


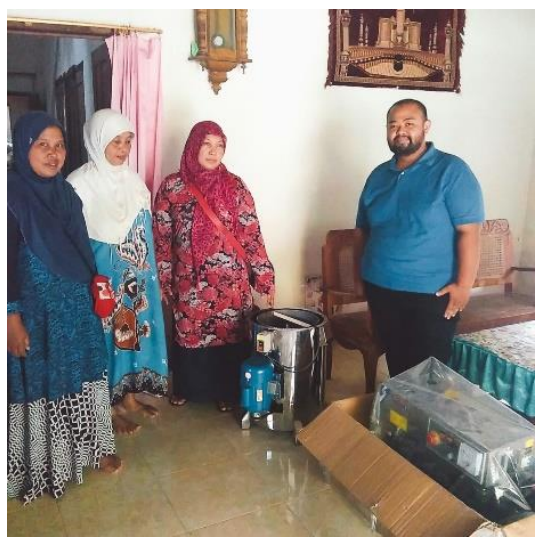

Gambar 7. Introduksi mesin spinner dan pengemas vertikal di UKM Mony

\section{Peningkatan kapasitas produksi kembang goyang}

Masalah yang dihadapi kembang goyang MONY produksi Ibu Nining Siti Muyasaroh adalah produk yang berminyak akibat bentuk kembang goyang yang mirip bunga mawar sehingga penuh lekukan. Untuk menghilangkan minyak diperlukan mesin pengatus minyak (spinner) tetapi dengan kecepatan putaran rendah karena produk kembang goyang mudah patah. Dalam program IbM ini kami mengintroduksikan mesin peniris minyak (spinner) dengan kapasitas 3-5 kg sekali proses dengan kecepatan putaran $700 \mathrm{rpm}$. Introduksi mesin spinner dan pengemas vertikal di UKM Mony dapat dilihat pada Gambar 7.

\section{Peningkatan pemahaman mitra terhadap GMP dan sanitasi industri pangan}

Dari beberapa kali peninjauan langsung ke lapang, dapat diketahui bahwa mitra belum sepenuhnya menerapkan prinsipprinsip GMP (Good Manufacturing Practices) atau cara-cara pengolahan pangan yang baik. Sosialisasi GMP dan standar sanitasi telah dilaksanakan ketiga mitra dan selanjutnya akan dipantau untuk melihat perkembangannya dalam kunjungan berikutnya. Sosialisasi GMP dan standar sanitasi dapat dilihat pada Gambar 8 .

Sebenarnya ke 3 mitra telah menyadari pentingnya GMP dan GMP wajib dipenuhi. Hanya saja dalam implementasinya, penerapan GMP membutuhkan pula dana yang cukup. Mitra ber-keinginan kuat bahwa ke depannya proses produksinya bisa sesuai GMP karena penerapan GMP meningkatkan keamanan produk olahannya serta mutu yang konsisten.
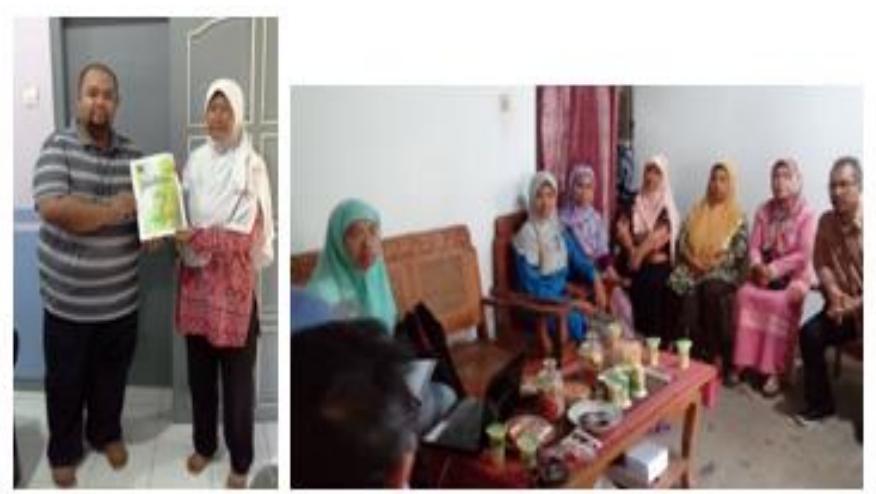

Gambar 8. Sosialisasi GMP dan standar sanitasi 

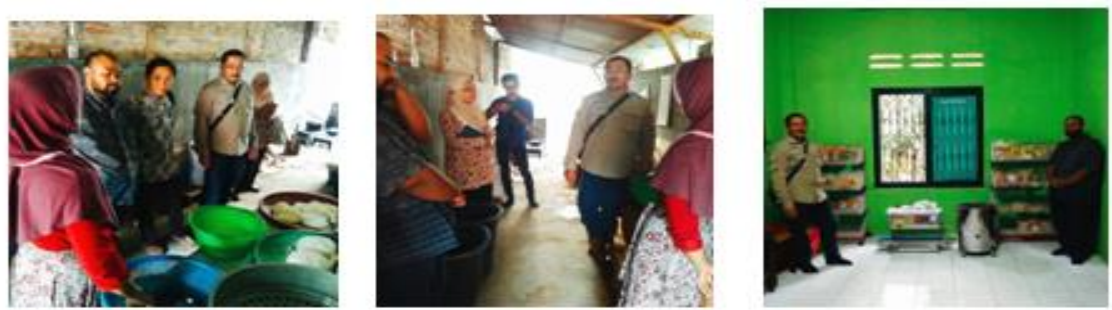

Gambar 9. Monitoring dan evaluasi lapang internal oleh team LPPM UB

\section{Monev lapang internal oleh team LPPM \\ Universitas Brawijaya}

Proses penjaminan mutu program IbM telah dilaksanakan dengan baik, salah satunya dengan adanya kegiatan monitoring dan evaluasi (monev) internal oleh team LPPM Universitas Brawijaya Malang. hari Jumat tanggal 16 September 2016. Foto kegiatan monev internal oleh team LPPM UB disajikan Gambar 9. Keseluruhan luaran kegiatan dalam program pengabdian Kegiatan monev internal ini dilaksakan pada masyarakat ini disajikan pada Tabel 1.

Tabel 1. Luaran kegiatan IbM Desa Papungan 2016

\begin{tabular}{|c|c|c|}
\hline Luaran & Sebelum program IbM & Setelah program IbM \\
\hline $\begin{array}{l}\text { Peningkatan efisiensi dan kapasitas } \\
\text { produksi opak gambir } \\
\text { - Peningkatan kapasitas pemarutan } \\
\text { - Peningkatan kapasitas dan efisiensi } \\
\text { pengemasan }\end{array}$ & $\begin{array}{c}3 \mathrm{~kg} / \mathrm{jam} \\
100 \mathrm{kemasan} / 4 \mathrm{jam}\end{array}$ & $\begin{array}{c}30-40 \mathrm{~kg} / 1-1,5 \mathrm{jam} \\
80-100 \mathrm{kemasan} / \mathrm{jam}\end{array}$ \\
\hline $\begin{array}{l}\text { Peningkatan mutu kembang goyang } \\
\text { - Pengatusan minyak }\end{array}$ & Produk berminyak & Produk tidak berminyak \\
\hline $\begin{array}{l}\text { Peningkatan efisiensi dan kapasitas } \\
\text { produksi rengginang dan kerupuk } \\
\text { kasava } \\
\text { - Peningkatan kapasitas pemarutan } \\
\text { - Peningkatan kapasitas dan efisiensi } \\
\text { pengukusan } \\
\text { - Peningkatan efisiensi granulasi }\end{array}$ & $\begin{array}{c}3 \mathrm{~kg} / \mathrm{jam} \\
80 \text { cetakan} / \text { batch } \\
30 \mathrm{~kg} / 4 \mathrm{jam} \text { atau } 7,5 \\
\mathrm{~kg} / \mathrm{jam}\end{array}$ & $\begin{array}{l}20 \mathrm{~kg} / \mathrm{jam} \\
160 \text { cetakan/batch } \\
30-40 \mathrm{~kg} / 1-1,5 \mathrm{jam}\end{array}$ \\
\hline $\begin{array}{l}\text { Peningkatan pemahaman mitra } \\
\text { terhadap Good Manufacturing } \\
\text { Practices dan sanitasi industri pangan } \\
\text { - Implementasi } 4 \text { butir GMP wajib }\end{array}$ & Belum implementasi & $\begin{array}{l}\text { Impelementasi } \\
\text { pengendalian proses, } \\
\text { suplai air, sanitasi pe- } \\
\text { kerja,pengendalian hama }\end{array}$ \\
\hline $\begin{array}{l}\text { - Sanitasi peralatan } \\
\text { - Sanitasi ruang produksi }\end{array}$ & $\begin{array}{l}\text { Tidak menggunakan } \\
\text { sarung tangan, } \\
\text { masker, penutup } \\
\text { kepala, cuci tangan } \\
\text { sebelum proses } \\
\text { Belum ada SOP } \\
\text { Belum ada SOP }\end{array}$ & $\begin{array}{l}\text { Menggunakan sarung } \\
\text { tangan, masker, penutup } \\
\text { kepala, cuci tangan } \\
\text { sebelum proses }\end{array}$ \\
\hline
\end{tabular}




\section{KESIMPULAN}

Alih teknologi mekanis yang telah diaplikasikan adalah proses pengemasan menggunakan mesin pengemas vertikal di UKM Mony, proses pemarutan mekanis serta penambahan kompor dan panci pengukus di UKM Agro Sukses Mulia. Adapun alih teknologi yang belum dapat diaplikasikan adalah proses pengatusan minyak di UKM Mony dan pemarut mekanis di UKM Rizky Abadi karena menunggu proses penyelesaian alat di bengkel serta pengukuran kinerja alat yang telah diintroduksikan terhadap kapasitas produksi mitra pada kunjungan lapang berikutnya. Sosialisasi GMP dan standar sanitasi juga telah dilaksanakan pada ke tiga UKM.

Setelah dilaksanakannya kegiatan IbM, ketiga UKM telah mampu meningkatkan kapasitas dan efisiensi produksinya. UKM Mony mampu meningkatkan kapasitas pengemasan opak gambir dan kembang goyang menjadi 80 100 kemasan per jam dan produk matarinya lebih kering dengan teknologi penirisan minyak. UKM Agro Sukses
Mulia mampu meningkatkan kapasitas pengukusan rengginang kasava menjadi $2 \mathrm{x}$ lipat yaitu 160 cetakan sekali proses dan meningkatkan kapasitas pemarutan singkong menjadi 1-1.5 jam untuk 30-40 kg singkong. UKM Rizky Abadi juga dapat meningkatkan efisiensi pemarutan 30 butir kelapa dalam waktu 1 jam dalam proses pembuatan opak gambir.

\section{DAFTAR PUSTAKA}

Bappeda Jatim. (2011). Pedoman Umum Pengembangan Kawasan Agropolitan Provinsi Jawa Timur Tahun 2011

Choe E. and DB Min. (2006). Mechanisms and factors for edible oil oxidation. Comprehensive Reviews in Food Science and Food Safety 5:169-186

Lee J, N Koo, and DB Min. (2003). Reactive oxygen species, aging, and antioxidativenutraceuticals.Comprehensive Reviews in Food Science and Food Safety 3:21-33 